\title{
JURNAL MERPATI
}

Media Publikasi Pengabdian Kepada Masyarakat Politeknik Pos Indonesia https://ejurnal.poltekpos.ac.id/index.php/merpati

\section{PELATIHAN ADMINISTRASI PERKANTORAN DAN TATA KELOLA KEARSIPAN DI DESA WANGUNHARJA KECAMATAN LEMBANG}

\author{
Angga Dewi Anggraeni ${ }^{1}$, Asaretkha Adjane ${ }^{2}$, Suparno Saputra $^{3}$, Dera Thorfiani ${ }^{4}$ \\ Manajemen Perusahaan, Politeknik Pos Inodnesia \\ ${ }^{1}$ anggadewi@poltekpos.ac.id, ${ }^{2}$ asaretkha@poltekpos.ac.id, \\ ${ }^{3}$ suparnosaputra@poltekpos.ac.id, ${ }^{4}$ dthorfiani@poltekpos.ac.id
}

\begin{abstract}
ABSTRAK
Desa Wangunharja merupakan salah satu desa yang berada di Kabupaten Bandung Barat di wilayah utara Kecamatan Lembang dengan luas wilayah 377,72 Ha. Batas Desa Wangunharja meliputi Desa-desa yang ada di Kecamatan Lembang keseharian masyarakat Desa Wangunharja adalah bercocok tanam, bertani, buruh tani, peternak sapi perah, TNI/POLRI, PNS dan buruh lainnya. Desa dengan segenap atribut pemerintahannya adalah arena yang berhadapan langsung dengan masyarakat. Perangkat desa mempunyai tugas membantu Kepala Desa dibidang Pembinaan dan Pelayanan Tehnis akademis, dan pelayanan Kepada Masyarakat. Keberadaan perangkat desa yang juga diserahi tugas dibidang administrasi, menduduki posisi yang sangat penting karena sebagai pemerintahan yang paling bawah seharusnya. Dengan adanya pelatihan ini, diharapkan akan menumbuhkan dan meningkatkan kesadaran perangkat desa Wangunharja untuk dapat mengelola arsip desa secara baik dan benar, membekali kemampuan dan keterampilan, perangkat desa untuk mengelola arsip sebagai upaya peningkatan pelayanan public, dengan demikian secara bertahap dan berkesinambungan nantinya kemampuan pemerintah desa dalam mengelola arsip akan semakin meningkat.
\end{abstract}

Kata kunci: Pelatihan, administrasi perkantoran, tata kelola kearsipan, desa wangunharja

\begin{abstract}
Wangunharja Village is one of the villages located in West Bandung Regency in the northern area of Lembang District with an area of 377.72 hectares. The boundaries of Wangunharja Village include villages in Lembang District. The daily activities of the people of Wangunharja Village are farming, farming, agricultural laborers, dairy farmers, TNI / POLRI, civil servants and other laborers. The village with all the attributes of its governance is an arena that faces the community directly. Village officials have the task of assisting the Village Head in the field of academic technical guidance and services, and services to the community. The existence of village officials who are also in charge of administration, occupy a very important position because they should be the lowest government. With this training, it is hoped that it will grow and increase the awareness of Wangunharja village officials to be able to manage village archives properly and correctly, equip their abilities and skills, village officials to manage
\end{abstract}


archives as an effort to improve public services, thereby gradually and continuously the capacity of the village government in managing archives will increase.

Keyword : Training, office administration, archival management, desa wangunharja

\section{PENDAHULUAN}

\subsection{Analisis Situasi}

Arsip adalah sumber dokumentasi dan informasi yang bisa membantu semua aktifitas sebuah institusi di bidang administrasi, birokrasi dan layanan publik, makna dasar arsip yakni dokumentasi I rekaman aktifitas dalam bentuk berbagai macam media yang digunakan, disesuaikan dengan perkembangan teknologi dan informasi yang berlaku pada saat itu (Octafiona, 2020). Arsip harus bersifat authentik, informasi utuh, berdasarkan azas asal usul dan aturan asli sehingga dapat digunakan sebagai alat bukti yang sah (Mindarti, 2020).

Tata kelola kearsipan memiliki peranan penting bagi setiap instansi tidak terkecuali bagi Pemerintah Desa Wangunharja, Kabupaten Bandung Barat. Desa dengan segenap atribut pemerintahannya adalah arena yang berhadapan langsung dengan masyarakat. Pemerintahan desa adalah perpanjangan tangan pemerintah pusat yang dipersonifikasi lewat Kepala Desa dan perangkatnya. Posisi pemerintahan desa juga sangat penting, mengingat mayoritas penduduk Indonesia tinggal di pedesaan. Kepala Desa dan perangkatnya sebagai pelaksana pemerintahan desa seharusnya memiliki kemampuan dalam mengelola administrasi, terutama perangkat desa yang berada langsung dibawah kepala desa. Perangkat Desa mempunyai tugas membantu Kepala Desa dibidang Pembinaan dan Pelayanan Teknis administrasi, dan Pelayanan kepada Masyarakat. Keberadaan perangkat desa yang juga diserahi tugas dibidang administrasi, menduduki posisi yang sangat penting karena sebagai pemerintahan yang paling bawah seharusnya.

\subsection{Permasalahan Mitra}

Desa memiliki potensi besar untuk dikembangkan menjadi desa mandiri. Desa juga memiliki kewenangan dalam mengatur urusan rumah tangganya sendiri sesuai dengan yang diatur dalam Undang-Undang Nomor 6 Tahun 2014 tentang Desa.

Arsip tercipta seiring berjalannya aktivitas instansi bersangkutan. Semakin besar instansi maka arsip yang terciptapun semakin banyak. Permasalahan yang terkait dengan penemuan kembali arsip yang dibutuhkan tentunya semakin kompleks sehingga membutuhkan pengelolaan arsip yang tepat. Permasalahan pengelolaan kearsipan dapat ditemui pada setiap tingkatan organisasi termasuk organisasi di tingkat pemerintahan desa yang memiliki tanggung jawab pelayanan kepada masyarakat.

Pelayanan masyarakat menjadi tugas utama dari pemerintah Desa dalam menjalankan roda pemerintahan desa, karena pada dasarnya keberadaan pemerintahan desa adalah untuk menyelenggarakan urusan pemerintahan dan kepentingan masyarakat setempat

\subsection{Tujuan Pengandian Masyarakat}

Dari uraian analisis situasi dan permasalahan di atas maka secara umum tujuan pengabdian kepada masyarakat ini adalah untuk Menumbuhkan motivasi dan meningkatkan kesadaran perangkat desa Mangunharja untuk dapat mengelola arsip desa secara baik dan benar ; Membekali kemampuan dan keterampilan perangkat desa untuk mengelola arsip sebagai upaya peningkatan pelayanan publik; Dengan demikian secara bertahap dan berkesinambungan nantinya kemampuan Pemerintah Desa dalam mengelola arsip akan semakin meningkat 


\section{METODE PELAKSANAAN}

Aktivitas yang ditawarkan dalam PKM untuk Desa Wangunharja Kabupaten Bandung Barat ini adalah memberikan fasilitasi pelatihan kearsipan dengan ruang lingkup sebagai berikut :

1. Modul dasar-dasar kearsipan admisnistrasi perkantoran

2. Modul kerja kearsipan admisnistrasi perkantoran

3. Modul persiapan kearsipan admisnistrasi perkantoran

4. Modul Laporan

Adapun metode yang digunakan untuk kegiatan pendampingan ditujukan untuk memonitor seberapa intensif dan efektif, perangkat Desa Wangunharja yang mengikuti kegiatan ini agar mampu mengelola arsip. Adapun tahapannya meliputi :

Tahap 1. Perencanaan

Pada tahap ini, solusi yang ditawarkan adalah memberikan pengetahuan untuk membuka wawasan pengetahuan dan pemahaman tentang arti penting pengelolaan arsip dan pelayanan prima bagi peningkatan pelayanan publik

Kegiatan yang dilakukan adalah mempersiapkan dan berkordinasi untuk mengadaan mobul dan alat peraga, serta memperhatikan permasalahan yang dimiliki oleh Desa Wangunharja.

Tahap 2. Pelaksanaan

Pada tahap pelaksanaan ini, melakukan pelatihan, diskusi dan pendampingan.

Kegiatan ini dengan cara memaparkan materi mengenai pengantar administrasi perkantoran dan tata kelola kearsipan, tujuannya adalah merubah cara kerja dari cara tradisional menjadi cara kerja profesional, sehingga pelayanan masyarakat dapat dilakukan secara efektif dan efisien. Setelah pemaparan selesai maka dilanjutkan dengan menguji coba metode dengan praktek menggunakan peralatan dan perlengkapan yang sudah disiapkan dengan cara memberikan simulasi.

Tahap 3. Evaluasi

Pada tahap ini, dilakukan evaluasi dari hasil pelatihan.

\section{HASIL DAN PEMBAHASAN}

Kegiatan pelatihan kearsipan admisnistrasi perkantoran sebagai peningkatan kemampuan diri di Desa Wangunharja ini dilaksanakan pada tanggal 11-12 Juli 2019 dengan pelaksanaan kegiatan meliputi:

1. Persiapan penyusunan modul pelatihan

2. Pemaparan materi pengantar kearsipan admisnistrasi perkantoran

3. Simulasi pemaparan kearsipan admisnistrasi perkantoran

Pelaksanaan kegiatan pelatihan diawali dengan pemaparan materi pengenalan kearsipan admisnistrasi perkantoran dalam penerapan Kearsipan di Desa Wangunharja, Setelah itu dilakukan simulasi kearsipan admisnistrasi perkantoran dan uji coba kearsipan admisnistrasi perkantoran, dan diakhiri dengan penutupan oleh Kades Desa Wangunharja. Tujuan dari pelatihan ini adalah untuk meningkatkan kinerja dan kemampuan tenaga administrasi yang ada di Desa Wangunharja Kabupaten Bandung Barat, dan mengubah cara kerja tradisional menjadi cara kerja profesional untuk meningkatkan pelayanan masyarakat. 


\section{KESIMPULAN}

Pelatihan kearsipan admisnistrasi perkantoran di Desa Wangunharja ini dirasa sangat bermanfaat bagi setiap pengurus dan anggota di lingkungan Desa Wangunharja dengan melihat antusiasme setiap peserta pelatihan dalam mengikuti pelatihan dan menguji kearsipan admisnistrasi perkantoran tersebut. Adapun kesimpulan dari pelatihan ini adalah sebagai berikut:

1. Kearsipan admisnistrasi perkantoran dapat dijalankan sesuai dengan standar operating procedure yang ditetapkan oleh Desa Wangunharja

2. Setiap modul dan tahapan kearsipan admisnistrasi perkantoran dapat dilaksanakan dengan baik oleh setiap peserta pelatihan.

\section{REFERENSI}

[1] http://wangunharja-lembang.sideka.id/profil/sejarah/ diakses pada tanggal 10 Juni 2019

[2] Mindarti, Lely Indah, dkk. (2020). Pemberdayaan Pelayanan dan Tata Kelola Kearsipan di Kelurahan Merjosari Kota Malang. Jurnal Pengabdian Masyarakat J-DINAMIKA, Vol. 5 No. 1. ISSN: 2503-1112.

[3] Octafiona, Era, dkk. (2020). Kearsipan Arsiparis Menggunakan E-Arsip dalam Tata Kelola Kearsipan Fakultas Tarbiyah dan Keguruan UIN Raden Intan Lampung. Jurnal Ilmu Perpustakaan dan Informasi Islam. P-ISSN: 2722-6980. Ejournal.radenintan.ac.id/index.php/elpustaka/index.

[4] Undang-undang Nomor 6 Tahun 2014 tentang Desa. 